\title{
'Return to the Lord your God, for he is gracious and compassionate...' (JI 2:13). A prophetic perspective on reconciliation and restoration
}

W J Wessels

(University of South Africa)

\section{ABSTRACT}

'Return to the Lord your God, for he is gracious and compassionate...' ( $\mathrm{Jl} 2: 13$ ). A prophetic perspective on reconciliation and restoration

In this article the Old Testament prophetic literature will be the focus of discussion with regard to the matter of restoring broken relationships, be it between God and humans or between humans as such. The relationship between Yahweh and his people was formally established by means of a covenant. The presentation of the prophetic material is done with a narrow focus on the issues of reconciliation and restoration. Prophets and prophetic texts are selected with the mentioned focus in mind and presented as the results of research done on the chosen texts. It is therefore done with a real awareness of the complexity of the prophetic material and the historical embedding of prophetic material. A detailed discussion of introductory and theological issues are therefore not presented, but taken into account. What result in this paper is a focussed presentation on the mentioned topics in some of the prophetic material. Although the word reconciliation is not an Old Testament concept, it is clear that the idea of re-establishment and renewal of the relationship between God and people was ever present. The prophets had the duty to address the reasons for damage to this covenant relationship and to warn the people of the consequences if they continue to disobey the stipulations and ethical demands of this relationship. The prophets not only served as witnesses of the efforts of Yahweh to reconcile with his people, but also as instruments to bring it about.

\section{INTRODUCTION}

The concept reconciliation has meaning in many contexts, and applies to everyday human relations and situations. It is a concept however which in particular has religious overtones. Reconciliation has to do 
with relationships which for some or other reason were damaged or scarred. The need normally exits to mend these damaged relationships to restore it to its former ideal state. The process to restore this relationship is converged in the concept reconciliation. When a relationship between two parties was damaged or harmed, it needs to be reconciled. This can be between human beings or in the religious context, between God and humans. To summarise: A relationship was damaged, a process was set in motion towards the healing of the relationship and the normalising of conditions. This is what is conveyed when the concept reconciliation is used.

The interest of this paper is a biblical understanding of reconciliation, in particular the section of the Bible which contains the prophetic views on the matter. The Bible has a great deal to say about the matter under discussion. One of the main focusses of the Bible concerns God and His endeavours to relate to human beings. Human beings were first of all created to be in relationship with Him and then in relationships with each other. God even took the initiative to formalise this relationship in a contractual way which demanded loyalty of both the parties in such a relationship. Both parties who entered into such a relationship had mutual expectations of one other. It is because of the breach of this mutual agreement that the relationships between God and humans were damaged and therefore a need to restore it. A process of reconciliation was required.

When the concept reconciliation is used in New Testament context, is it loaded with religious overtones concerning Jesus Christ. It became a technical term for the work done by Christ to heal the damaged relationship between God and people. The process involved in setting things right between God and humans because of sin, required the sacrificial dying of Christ on the cross, paying the price to reconcile humans with God. Reconciliation in New Testament regard has everything to do with Christ and his substituting death on the cross. In the Old Testament however, it is a different matter.

The concept reconciliation does not appear in the Old Testament as such. The fact however that the concept does not appear in the Old Testament, does not imply that tendencies towards reconciliation are absent. The Old Testament is all about God and his relationship with a people who He has chosen to relate to intimately. It is also all about 
how his relationship with his chosen people affects their relationships with other human beings. When the relationship between God and his people has suffered damage of a kind, the need existed to rectify the situation and to restore it. Different terminologies were used to indicate what was needed for the process of restoration. Some of these terms are atonement, restitution, repentance, forgiveness and restoration.

In this paper the Old Testament prophetic literature will be the focus of discussion with regard to the matter of restoring broken relationships, be it between God and humans or between humans as such. The presentation of the prophetic material is done with a narrow focus on the issues of reconciliation and restoration. Prophets and prophetic texts are selected with the mentioned focus in mind and presented as the results of research done on the chosen texts. It is therefore done with a real awareness of the complexity of the prophetic material and the historical embeddedness of prophetic material. A detailed discussion of introductory and theological issues are therefore not presented, but taken into account. What results in this paper is a focussed presentation on the mentioned topics in some of the prophetic material. Before presenting the discussion on the prophetic texts, a look at the prophets of the Old Testament and their roles as agents of restoration is necessary.

\section{OLD TESTAMENT PROPHETS AND THEIR ROLES}

Quite a number of prophets acted in the Old Testament. Some of the books in the Old Testament tell of their heroic stories and deeds, while others contain the words of the prophets. To date many scholars have made efforts to present views on the origin, social locations, diverse roles and social impact of the prophets (cf for example Wilson 1980; Blenkinsopp 1996; Davies 1996 and more recently Arthur 2001; McConville 2002; Petersen 2002; McKenzie and Graham 1998). These scholarly works can be consulted for a detailed discussion on the prophets. For the purpose of this paper, the writing prophets are the focus of the discussion on reconciliation and restoration. The ministries of the prophets to a great extend coincided with the kingship in Israel and Judah. Prophets were regarded as messengers of God to these kings and their people. Their role in the community entailed to speak on behalf of God, proclaiming messages of doom and salvation. At times their task was to bring good news and comforting messages, but at 
times they had to speak harsh words of reprimand and punishment. Goldingay $(2003: 673,687)$ refers to them as 'powerful men whom God sends', 'Yahweh's aides'.

They had a very particular role to play in the establishment and maintenance of the relationship between God and his people. It also implied a role in the relationship between people in their respective societies which had to act in a way which would honour their relationship with God. Prophets were people called with the purpose to contribute in some or other way to relationships between God and humans and people with each other. Brueggemann (1997:622-649) shows this in his Old Testament Theology by contributing a chapter to the prophets under the heading 'The Prophet as Mediator'.

The relationship between God and his people was formalised in a covenant. This covenant was a formal agreement of loyalty and obedience between God and his people. This implied that God has chosen a people to be his people. By doing so, He made the promise to love and care for them as his part of the agreement. From them was expected to serve Him with loyalty and to obey his commands. They had to act ethically towards Him, but also to all people in their respective societies. Loyalty implied that they had to worship Him alone and no other gods. Because of their love and loyalty, they were required to seek to know Him better, to understand how He wants them to live and to obey his commands. He wanted them to seek the truth, to act justly and ethically and to honour Him. In all of this, the prophets were regarded as key figures in the process of achieving this ideal (cf Petersen 2002:37-39). They had a crucial role to play in helping to build and maintaining the constructive relationship between God and his people (cf Gowan 1998:9). They were regarded as agents and protectors of the covenant relationship between God and his people(cf Brueggemann 1997:645). In a positive sense they had to contribute constructively in strengthening this covenant relationship. On the negative side they had to reprimand the people and speak on God's requirements for this relationship to continue or even the termination of this relationship. They often urged the people of God to 'turn around' and mend their ways. The prophets had a major role to play in the process of reconciling God with his people in cases where the 
relationship was harmed. In this paper their role in restoring relationships and reconciling different parties will be highlighted.

\section{THE PROCESS OF RECONCILIATION AND RESTO- RATION}

The key matters to be considered in discussing reconciliation is relationship and communication. Broken or damaged relationships lead to a lack of communication and therefore no real community. In the discussion to follow, attention will be given to the nature of relationships, causes of harm to these relationships, the message of the prophets, the process of healing and restoring relationships and finally, the results of reconciliation.

When reading the prophetic material with an eye for relationships, the focus is predominantly on the relationship between God and his people. Much of the material entertain the dissatisfaction of God because of his people's unfaithfulness to Him. It is however important not to regard this primer relationship as unconnected to the social situations of everyday life. God's commands do not only demand loyalty and faithfulness to Him, but also involves every aspect of his peoples actions and behaviour in society. How people interact concerns God closely and impacts on his relationship with them. The triangle of God linked to his people, his people to Him and people to each other, shows they are unquestionably inter-connected. This is aptly illustrated in Micah 6:8

"He has showed you, O man, what is good. And what does the LORD require of you? To act justly and to love mercy and to walk humbly with your God" (NIV).

As mentioned before, reconciliation and restoration is a process. When reading the prophetic books, a general picture emerges of the process involved in reconciling God and people. In this whole endeavour the prophets played an instrumental role in facilitating the process of restoration. In general the following occurred: A transgression was committed which affected the relationship with Yahweh negatively. This transgression was typified under the generic concept 'sin', meaning something done which displeased God. Following this, the messengers of Yahweh are instructed to admonish the people or even to proclaim a message of condemnation and punishment. The requirement 
was usually to 'turn around' or 'to turn away from' that which displeases Yahweh and is a breach of the covenant between them. A positive response, which means obedience, usually led to a confession of what was done wrong. This confession was accompanied by acts of penance, to bring atonement and do restitution of the relationship. Accompanying this was God's forgiveness as his response to their confession and atonement. Reconciliation then led to normalisation and renewal of the relationship. The nature of the 'sins' the people of Israel and Judah committed comprised not only their disloyalty to Him by worshipping foreign gods, but in many instances social transgressions which were committed. God required his people and the leaders in particular, to have a sense of justice and fairness. This had to be reflected in their daily conduct with people. The leaders had to see that justice prevails and that those who have no rights, the widows and the orphans in particular, received fair treatment. Societal relationships directly affected and reflected the nature of the relationship between God and his people.

\subsection{The relationship between Yahweh and his people}

As was mentioned, a formalised relationship between God and the people of his choice existed. This relationship was established by means of a covenant. Israel and Judah were regarded a covenant people with many privileges because of the covenant agreements, but also many obligations. The nature of this relationship found expression in different ways. One such expression was the use of the marriage metaphor in the books of Hosea and Jeremiah. Sandy (2002:59-74) has shown how powerful the use of metaphors can be and refer to it as '...the lifeblood of prophecy'.

\subsubsection{Hosea}

In the eighth century a prophet by the name Hosea acted in the Northern Kingdom, also known as Israel (cf Blenkinsopp 1996:82-90). Hosea was commanded by God to marry a woman by the name of Gomer. She was depicted as an adulterous wife. Because of the unfaithfulness of Gomer, their marriage served as a symbol of the unfaithfulness of Israel to God. Gomer acted out the role of unfaithful Israel and was in a marriage relationship (covenant) with Hosea, representing God. The children born out of this wedlock were then 
given names which symbolised the broken relationship between God and his people. The two most significant names were Lo-ruhamah, meaning 'not pitied' and the other Lo-ammi, 'not my people'. It is clear from these names that God recalled the covenant privileges because of Israel's unfaithfulness and that judgment was looming (cf Petersen 2002:176-181).

Is it a question as to what went wrong. The mother who has turned harlot served as a metaphor for the fact that Israel has turned to other gods like Baal, instead of worshipping and depending only on the God of the covenant. They worshipped the nature gods for their livelihood, instead of trusting God for their daily needs such as rain, good crops and vegetation. In Hosea 4 it becomes clear that Israel's unfaithfulness and lack of knowledge of God showed in their everyday conduct,

"...there is swearing, lying, murder, stealing, and committing adultery; they break all bounds, and bloodshed follows bloodshed" (Hs 4:2, ASV).

The outcome of all of this is God's punishment. This punishment will show in agriculture mishaps and failure (cf Hs 2:8-12), religious instability (cf Hs 4:4-19) and international instability (cf Hs 5).

In spite of Yahweh's anger and frustration with his people, the book of Hosea testifies to the great mercy of God. What is most significant from his relationship with his people is his attitude of still taking responsibility for re-establishing the relationship. It is clear that He will do everything possible to heal the relationship (cf Hs 7:1). He kept calling on his people through the prophet to return to Him, seek to know Him and to be loyal to Him alone. But the first move towards reconciliation between God and Israel came from Yahweh. Already in chapter 2 of Hosea He made his intentions clear to 'court' Israel again, taking her back to the desert where she was completely dependant on Him, and showing her his steadfast love and mercy (cf 2:19). In Hosea 2:23 Yahweh declared:

"I will plant her for myself in the land; I will show my love to the one I called 'Not my loved one'. \{23 Hebrew Lo-Ruhamah\}. 'I will say to those called 'Not my people, $\{23$ Hebrew Lo-Ammi\} "'You are my people'; and they will say, 'You are my God'” (NIV) 
In Hosea 14 on the call for Israel to return to Yahweh and be faithful to Him, Yahweh's response in indicated

"I will heal their apostasy; I will love them freely, for my anger has turned from them” (Hs 14:4; ASV).

The result of the 'healing' will be revealed in Yahweh's blessing in the sense that Israel would be like blossoms, the trees of Lebanon, the olive trees, the grain, the vines, the wine. It creates the impression of prosperity and social well-being.

When reading the book of Hosea, one is left with the impression that although the call to the people of God was to return, to show their loyalty and trust and obey Him, that it was not a prerequisite for Him in seeking to re-establish his relationship with them and to reconcile with them. The focus is on his love, his mercy and his compassion (cf Petersen:180-181).

\subsubsection{Amos}

Another Northern Kingdom prophet of the eighth century was Amos from Tekoa. He acted as prophet in a time when prosperity and peace were experienced during king Jeroboam II's reign (cf Gowan 1998:2425). Although it was a time of great prosperity, the prophet spoke on behalf of Yahweh against the many injustices in the society at that time. The actions of people clearly violated the stipulations of the covenant. This happened in the religious practices (Am 2:8; 4:4; 5:21-24), in the economic life $(2: 6 ; 5: 11 ; 8: 5)$, but also in legal matters (cf $5: 15$ ). In particular, the poor and the needy were exploited $(2: 6 ; 4: 1 ; 5: 12 ; 8: 4)$, which was totally unacceptable to Yahweh. The book of Amos speaks out in favour of righteousness and justice. The lack of these mentioned aspects angered Yahweh and therefore Amos had to proclaim the coming judgement of the people of Israel. They awaited a 'Day of Yahweh'. Such a day was to come, but it would be a day of judgment because of Yahweh's dissatisfaction with the people of Israel. It is clear from the book of Amos that the relationship between Yahweh and the people of Israel was damaged because of social misconduct, meaning injustices and the lack of fairness to all people. It was also of no use to go to holy places to worship Yahweh, but at the same time exploit people and deny them of their rights. This is nothing less than hypocrisy. 
In order to avoid this imminent punishment at the hand of Yahweh, the prophet called on the people of Israel to abandon their destructive behaviour and once again to act in accordance to the covenant requirements. Some of the admonitions commenced with calls such as 'Seek me and live' (5:4), 'Seek Yahweh and live' (5:6) and 'Seek good and not evil' (5:14). Other appeals to them assured that by taking heed, they could avert the coming judgment of God (5:18-20). It seems from the book Amos that the people did not react favourably to the calls to amend their ways of doing, resulting finally in their captivity in 722 BCE.

The book Amos, however, does not end without the prospect of hope for the future (the positive end of the book Amos raises many questions, cf. e.g. a Gowan 1998:36-37; McConville 2002:165-166, 171-172). Yahweh, the Lord of the covenant, did not totally relinquish his people. As the initiation of the covenant relationship was his idea, so a new beginning would also be his doing. Amos speaks of a restoration of David's tent and a renewal of the land. It leaves room for a return and possible restoration of their relationship with Yahweh their God. A new beginning therefore seemed possible for those who will seek Yahweh, return to Him and find forgiveness and renewal of their relationship. To arrive at a newly reconciled relationship in this case seemed challenging in the sense that hardship was unavoidable and inescapable. The route to reconciliation in this regard was via the experience of hardship. But the promise of a new beginning remained a possibility and therefore hope as well.

\subsubsection{Joel}

The prophet Joel is another one of prophet who addresses the issue of a people who went astray and had to be warned to return to God. It is difficult to date the book of Joel and it is therefore senseless to speculate on it (cf McConville 2002:152-155; Blenkinsopp 1996:224). The book commences with an image of locusts reaping the fields, leaving a scene of devastation behind them. The image which seems very real moves into a description of an invading army threatening most probably the people of Judah. Similar to the book of Hosea, this depiction of Yahweh's punishment was followed by images of agricultural catastrophe ( $\mathrm{cf} 1: 10-12 ; 15-20$ ). This caused the people to

experience hardship because of the divide that has occurred between 
Yahweh and his people. In several of the prophetic books the imagery of locusts are utilised to indicate that 'the day of Yahweh' is imminent, which would be a day judgement (cf Am 4:9; Nh 3:16b, 17; Hb 1:9 and Ml 3:10; cf Collins 2004:421).

Although it is not clearly indicated what the people Joel was addressing did wrong, it seems that they were disloyal to Yahweh. They thought by performing rituals they could please Him. What God expected them to do, required much more than ritualistic practices (cf Gowan 1998:183-184). He was not interested in superficial religious motions. In 2:12-14, Joel clearly indicated what Yahweh expected from his people. He said:

"'Even now', declares the Lord, 'return to me with all your heart, with fasting and weeping and mourning'. Rend your heart and not your garments. Return to the Lord your God, for he is gracious and compassionate, slow to anger and abounding in love, and he relents from sending calamity. Who knows? He may turn and have pity and leave behind a blessing - grain offerings and drink offerings for the Lord your God” (NIV).

From the quote above, that vocabulary clearly reflects the language which applies to the covenant relationship between God and his chosen people. It is also clear that if the people whole-heartedly turn to Yahweh, his response to their efforts would bring about positive change. This for instance would show in nature and in the agriculture activities. They will again experience prosperity and their pride will be stored (cf 2:21-27). It also seems from Joel 2:28-32 that the people would have a new experience of his presence. His Spirit will open up ways of communication between Yahweh and his people as indication of a restored relationship and reconciliation between them (cf McConville 2002:156-157). Joel does not declare religious practices like offering, fasting and weeping as redundant, but demands inward sincerity and honesty to accompany these practices. Only this would lead to true reconciliation and restoration.

\subsubsection{Micah}

At the end of the eighth century a prophet named Micah acted in Jerusalem in the Southern Kingdom. This book named after the prophet Micah also had a strong focus on social injustices which dissatisfied 
Yahweh. Rich landowners made plans to deprive weak members of society like widows and orphans of their heritage, the land that God gave them as a gift (cf Mi 2; cf Pleins 2001:381-382). Not only were the rich landowners in the scope of the prophet's proclamation of judgment, but also the religious leaders such as the prophets and the priests. They were criticised for being false prophets by speaking what the people wanted to hear, pretending it to be revelatory words received from God. The priests were teaching but demanded money and judges took bribes in order to please the people (cf Mi 2 and 3). Against these formidable insider enemies, the prophet Micah took a stand claiming authority and power from Yahweh (3:8). These social and religious iniquities of the leaders resulted in Yahweh announcing that He will turn his face away from them (3:4), the prophets not receiving any revelations in the form of visions and the seers not receiving any answers from Yahweh (3:7). The end result according to Micah would be the destruction of Jerusalem and the temple. This was severe punishment because Jerusalem was the city of David and the temple the earthly abode of Yahweh. The very symbols of their security would be swept away, leaving them extremely vulnerable (Dempsey 2000:3031).

Micah 6:9-16 in greater detail spells out the nature of the transgressions which surfaced in every day society of Micah's time. They were blamed for dishonesty in the market-place and the rich people for their acts of violence and their lies. Chapter 7 elaborated further on this by indicating that even in family setups no one could be trusted. This resulted in the words of Micah 6:13:

"Therefore, I have begun to destroy you, to ruin you because of your sins” (NIV).

From Micah 6:1-7 it seems that the people of Judah thought that they could avert God's anger and punishment by simply bringing Him various sacrificial offerings. To this Micah 6:8 makes it clear that Yahweh was not satisfied with rituals and simply going through certain motions to try and please Him. Yahweh required a particular attitude and a way of living: 
"He has showed you, O man, what is good. And what does the Lord require of you? To act justly and to love mercy and to walk humbly with your God” (NIV).

According to Micah all was not lost. In Micah 7:8 a confession of faith is expressed that in spite of punishment Yahweh could still be regarded as a 'light' to the believer. This is followed in verse 9 with a confession of $\sin$ and an expression of trust that Yahweh will restore the relationship. It is said:

"Because I have sinned against him, I will bear the Lord's wrath, until he pleads my case and establishes my right. He will bring me out into the light; I will see his righteousness" (NIV).

The question could be asked on what grounds the restoration and reconciliation would take place? In Micah 7:18 and 19, knowledge of Yahweh is expressed as He has shown himself to be in relationship with his people. It is confessed:

"Who is a God like you, who pardons sin and forgives the transgression of the remnant of his inheritance? You do not stay angry forever but delight to show mercy. You will again have compassion on us; you will tread our sins underfoot and hurl all our iniquities into the depths of the sea" (NIV).

The language of reconciliation and renewal is clear from these verses: pardon of sins, forgiveness, mercy and finally compassion (cf Collins 2004:324).

\subsubsection{Zephaniah}

The theme of the 'day of Yahweh' is also prominent in the book of Zephaniah. This prophet acted in the time of king Josiah, known for his reforms (cf McConville 2002:219). Zephaniah proclaimed a message of judgment to the nations of the world, but in particular to the people of Judah. Yahweh was not satisfied with Judah, who worship Him as their God, but at the same time paid homage to foreign gods. He was also disturbed by the violence and deceit of people (1:9). Yahweh was also dissatisfied with the wealthy people in the society and the social injustices which accompanied their way of living. It seems that there was a sense of pride raging amongst the people which was not acceptable. Yahweh was angry because they have sinned against Him 
(1:17). In chapter 3:1-4, Yahweh's anger against the leadership in Jerusalem, both civil and religious, is expressed. Because of all of this Zephaniah announced that 'the day of Yahweh', a day of judgement could surely be expected and was near. Yahweh will show his wrath and ashamed all of those did wrong to Him.

However, the possibility was also raised that it could be avoided. In Zephaniah 2:3 it is said that the people should 'seek Yahweh':

"Seek the Lord, all you humble of the land, you who do what he commands. Seek righteousness, seek humility; perhaps you will be sheltered on the day of the Lord's anger" (NIV).

It became apparent that Yahweh would punish those who rejoice in their pride (3:11). But contrary to these people, there would be a number of people (a remnant) towards whom Yahweh will act differently. Zephaniah 3:12-13 reads:

"But I will leave within you the meek and humble, who trust in the name of the Lord. The remnant of Israel will do no wrong; they will speak no lies, nor will deceit be found in their mouths. They will eat and lie down and no one will make them afraid" (NIV).

In the last section in Zephaniah a change of fortune is announced for the people who put their trust in Yahweh (cf Petersen 2002:204-205). This will once again show his mercy in his connection with his people. He will renew the relationship with them and restore their honour in the world. It will be like a new beginning (cf House 2003:332-333). They will be in good stand with Him as his people.

\subsubsection{Jeremiah}

In the book of Jeremiah the focus on the covenant relationship between Yahweh and his people is very prominent (cf Brueggemann 1998:4-7). In this lengthy book there are many passages which call on the people of Judah to acknowledge the covenant once again and to obey Yahweh their God. Jeremiah has emphasised that Judah are a people because of God's mercy to enter into a relationship with them. He is their God and they are his people. That was the nature of the relationship with them.

But it is also very clear from Jeremiah that the people of Judah has failed miserably in their loyalty to Yahweh. In fact, Jeremiah has blamed them that their behaviour do not testify to any knowledge of 
what Yahweh requires of them. Not only were they disloyal by worshipping foreign gods, but even their social conduct was corrupt and immoral. Instead of protecting justice and acting righteously, they committed offences such as oppression, bloodshed and deceit (cf Jr 7). In this way they have alienated themselves from the God of the covenant and evoked his wrath. They were guilty of $\sin$ and transgressions. Both their relationships with God and the people of their society were blemished. Jeremiah were called by Yahweh to address these issues and warn them to amend their ways of doing or face the judgement. From the book it is clear that the people of Judah did not listen to the messenger of Yahweh and did not obey the call to change their behaviour.

The natural outflow of this was a damaged relationship with Yahweh and punishment. The punishment was severe and brought a turning point in the history of Judah. Yahweh used the super power, the Babylonians, to bring about punishment. This powerful nation besieged Jerusalem and destroyed the temple of Yahweh. They then took the leaders and people of skill from the society in Judah into exile where they had to stay as foreigners in Babylon. This was not the first time that Yahweh exercised punishment on his covenant people by using a foreign power. In the time of Isaiah He used the Assyrians to punish the people of Israel by allowing them to take the people of the Northern Kingdom into exile to Nineveh.

A very important issue which needs to be raised, is the role of religion in justifying wrong behaviour. The people of Judah felt very secured in their relationship with Yahweh. Their confidence was built on the fact that they were Yahweh's people, sealed with a formal covenant. Besides this, God made a covenant with the house of king David that there will always be a king in the lineage of David on the throne. He will rule in the city of David, Jerusalem, where his palace will be located. But even more important than this, was the fact that Yahweh's temple was in Zion (Jerusalem), which means that He was in their midst in his earthly abode. These symbols created a sense of false security and therefore a sense of one may say, arrogance. Because of this, the people took Yahweh's presence for granted (cf Jr 7:1-15). They no longer humbled themselves before Yahweh or realised their dependence on his mercy and grace. They did evil things in the eyes of 
Yahweh as mentioned before and thought that while the symbols of their security are still in place, their actions were justified. Jeremiah had a strong message from Yahweh that He was dissatisfied and rejects their attitude. Therefore He would punish them. They would no longer have the privilege to worship in the temple in Jerusalem and there would no longer be a king from the lineage of David on the throne (for more discussion of issues in the book of Jeremiah see e.g. Carroll 1986; Pleins 2001:276-318; Collins 2004:334-347).

From the book of Jeremiah we know that this was not the final episode in the history of the people of Judah and Israel. Jeremiah's message was that a group of purged people will survive the ordeal of the exile and would one day again return to the land of Judah and will be a renewed people of God. The faithful therefore had to newly establish their identity as the people of Yahweh in the absence of the temple as symbol of his presence. This they did by regrouping themselves around the Law of Yahweh to confirm their identity as his people. To these faithful Yahweh promised to establish a new covenant to confirm his relationship and loyalty to them once again. We read in Jeremiah 31:31-34 the following:

"The time is coming”, declares the Lord, "when I will make a new covenant with the house of Israel and with the house of Judah. It will not be like the covenant I made with their forefathers when I took them by the hand to lead them out of Egypt, because they broke my covenant, though I was a husband to them", \{Or was their master declares the Lord. "This is the covenant I will make with the house of Israel after that time", declares the Lord. "I will put my law in their minds and write it on their hearts. I will be their God, and they will be my people. No longer will a man teach his neighbor, or a man his brother, saying, 'Know the Lord', because they will all know me, from the least of them to the greatest”, declares the Lord. "For I will forgive their wickedness and will remember their sins no more" (NIV).

Although Yahweh took harsh measures to punish his disloyal and disobedient people, it was once again He who showed his mercy and established a new relationship with them. It was he who again initiated the process of reconciliation. In the third part of the book of Isaiah, this new beginning of God with his people was referred to as a new exodus 
form bondage. This implied renewed care for his people (cf Is 51). Isaiah said that Yahweh would take care of them, treat and heal their wounds (Is 57:14-21) and again make them a blessing and a shining light to the nations (Is 60-61). They will again be a people reconciled with Him, a people to his honour and joy.

The idea of reconciliation and restoration is surely present in the book of Jeremiah. As indicated, traces of this are evident throughout the book. Judgement is not a course in itself, in the long run it was Yahweh's aim to restore the relationship with his people. He will again 'plant' and 'build' them (cf Gowan 1998:114-117; Collins 2004:344346).

\subsubsection{Zechariah}

A final example to illustrate Yahweh's intentions to reconcile with his chosen people, is the book of Zechariah. This book shares with the book of Haggai the time of the return of the people from Babylonian exile and the re-establishment of the people in Judah (cf Gowan 1998:162-170). This included the restoration of Jerusalem and the rebuilding of the temple. This book testifies to expectations of return and regaining what was lost because of the exile. It also testifies to renewal of their relationship with Yahweh. This will take place under the leadership of a descendent of king David, but now accompanied by a high priest who will see to it that the Law gets the deserved recognition. The book of Zechariah proclaims the return from exile as a deed of mercy and grace from Yahweh. The call is to the people in exile to respond to the mercy of Yahweh by seeking, repenting and returning to Yahweh. The promise is made that days of blessing can be expected, even for the nations of the world. Judgment has led to repentance and repentance resulted in renewal. Whereas the 'day of Yahweh' at some stages in history resulted in judgment for Israel and Judah, according to Zechariah in future it will negatively affect those who oppose the Jerusalem and the people of Judah (cf 12:1; 14:1-5). However, the people of Yahweh will draw benefits from this day. The future will testify to renewal of the relationship between God and his people and the restoration of Jerusalem and even the creation (cf Collins 2004:414; Blenkinsopp 1996:233-235; Petersen 2002:207-209). 


\section{CONCLUDING REMARKS}

Although the word reconciliation is not an Old Testament concept, it is clear from the discussion that the idea of re-establishment and renewal of the relationship between God and people was ever present. The prophets had the duty to address the reasons for damage to this covenant relationship and to warn the people of the consequences if they continue to disobey the stipulations and ethical demands of this relationship. At times the prophets had to proclaim God's judgment and had to call on the people to confess their wrong-doing and return to Yahweh their God. At times they also had the privilege to announce Yahweh's mercy and his intentions to renew the relationship with his people. They also had to express his care and convey the blessings He had in mind for them. The prophets not only served as witnesses of the efforts of Yahweh to reconcile with his people, but also as instruments to bring it about. From the discussion it is also clear that reconciliation and restoration remains primarily a divine initiative to which humans should graciously respond.

\section{Consulted literature}

Arthur, D 2001. A Smooth Stone. Biblical Prophecy in Historical Perspective. New York: University Press of America.

Birch, B C, Brueggemann, W, Fretheim, T E and Petersen, D L (eds) 1999. A Theological Introduction to the Old Testament. Nashville: Abingdon Press.

Blenkinsopp, J 1996. A history of prophecy in Israel. Revised and Enlarged. Louisville, Kentucky: Westminster John Knox.

Brueggemann, W 1997. Theology of the Old Testament. Testimony, Dispute, Advocacy. Minneapolis: Fortress Press.

-, 1998. A Commentary on Jeremiah. Exile and Homecoming. Grand Rapids: Eerdmans.

Chisholm, R B 2002. Handbook on the Prophets. Grand Rapids: Baker Academic.

Collins, J J 2004. Introduction to the Hebrew Bible. Minneapolis: Fortress Press.

Davis, P R (ed) 1996. The Prophets. A Sheffield Reader. Sheffield: Sheffield Academic Press.

Dempsey, C J 2000. The Prophets: A Liberation-Critical Reading. Minneapolis: Fortress Press.

Goldingay, J 2003. Old Testament Theology. Israel's Gospel. Downers Grove, Illinois: InterVarsity Press. 
Gowan, D E 1998. Theology of the Prophetic Books. The Death and Resurrection of Israel. Louisville, Kentucky: Westminster John Knox.

Holmgren, F C 1999. The Old Testament and the Significance of Jesus. Grand Rapids, Michigan: Eerdmans.

House, P R 2003. Endings as New Beginnings: Returning to the Lord, the Day of the Lord, and Renewal in the Book of the Twelve, in: Redditt, P L and Schart, A (eds), Thematic Threads in the book of the Twelve. New York: Walter de Gruyter, 313-338.

McConville, G 2002. Exploring the Old Testament. The Prophets, Volume 4. London: SPCK.

McKenzie, S L and Graham, M P (eds) 1998. The Hebrew Bible Today. An Introduction to Critical Issues. Louisville, Kentucky: Westminster John Knox Press.

Nogalski, J D and Sweeney, M A (eds) 2000. Reading and Hearing the book of the Twelve. Atlanta: Society of Biblical Literature.

Petersen, D L 2002. The Prophetic Literature. An introduction. Louisville, Kentucky: Westminster John Knox Press.

Redditt, P L and Schart, A (eds) 2003. Thematic Threads in the book of the Twelve. New York: Walter de Gruyter.

Sandy, D B 2002. Plowshares and Pruning Hooks. Rethinking the Language of Biblical Prophecy and Apocalyptic. Downers Grove, Illinois: InterVarsity Press.

Wilson, R R 1980. Prophecy and Society. Philadelphia: Fortress Press. 